\title{
THE DISTRIBUTION OF MAMMALS IN SOUTHEASTERN ALBERTA AS INDICATED BY THE ANALYSIS OF OWL PELLETS*
}

HUGH C. SMITH, Provincial Museum of Alberta, 12845-102 Avenue, Edmonton, Alberta. T5N $0 \mathrm{M} 6$

Although the food habits of most species of owls are fairly well documented in North America, few studies have been made on the diets of owls in Alberta. Rusch et al. studied Great Horned Owls at Rochester, Smith reported on the food habits of seven species of owls in the Edmonton area, and Boxall studied Snowy Owls in the Calgary area. ${ }^{891}$ In 1980, large numbers of pellets from Great Horned Owls and Burrowing Owls were collected in southeastern Alberta. The present study was not undertaken to ascertain the food habits of these owls, but rather to obtain information on the distribution of the mammals that served as prey for these owls. Pearson and Pearson suggested the feasibility of using mammal remains found in owl pellets to determine the distribution of mammals in an area. ${ }^{7}$ The pellets from Great Horned Owls and Burrowing Owls are good candidates for this type of study because both owls are opportunistic and catholic predators. ${ }^{85}$

\section{Methods}

Pellets were collected from various sites within the area bounded by Townships 2 and 25 and by Ranges 4 and 17 west of the fourth meridian, approximately 3225 square km (2016 square mi). The majority of the sites were from a much smaller area,

* Natural History Contribution No. 69 however, approximately 873 square km (546 square mi). Great Horned Owl pellets were collected from 19 sites and Burrowing Owl pellets from 18 sites. The number of pellets per site ranged from one to approximately 100 . No attempt was made to count the number of pellets from any site as frequently the pellets were in a broken condition. The Great Horned Owl pellets were collected from

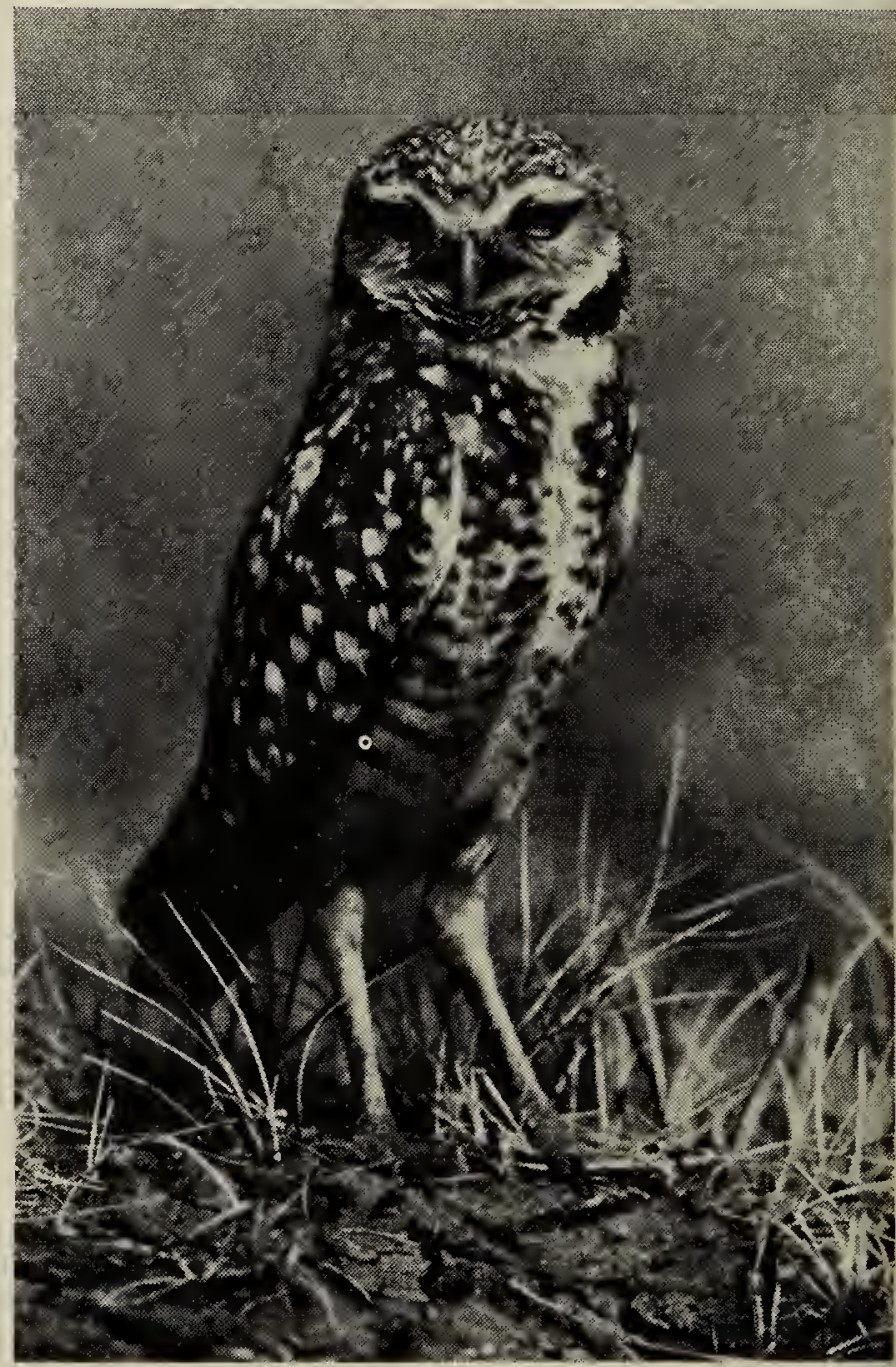

Burrowing Owl.

Wayne Lynch 
late winter to early spring 1980 and the Burrowing Owl pellets were collected in early summer 1980.

Pellets were broken apart and all bone and insect parts were sorted. Identification of bone material was made by direct comparison to a reference collection of skeletons. The lower jaws were most often used to identify the mammals and several bones, the humerus and tibiotarsus, were used to identify the birds. The number of individuals of any species was determined by matching pairs of elements of similar size. For mammals the lower jaws were used and for birds the humeri. This method is extremely crude and no doubt underestimates the number of individuals actually captured. No attempt was made to identify the species or remains of salamanders, gartersnakes, or insects recovered in pellets.

\section{Results}

Species, location, and number of individuals from the Great Horned Owl pellets are shown in Tables 1 and 2 and from the Burrowing Owl pellets in Tables 3 and 4.

The number of birds and mammals identified from the pellets of both owls was 1756. Of these 1122 individuals of 18 species of mammals and 123 individuals of 32 bird species were in the Great Horned Owl pellets and 483 individuals of 10 species of mammals and 30 individuals of 9 species of bird were from the Burrowing Owl pellets. In addition, insects and salamanders were found in pellets of both owls, but gartersnakes were found in the pellets of only burrowing owls.

The percentages of bird and mammal prey was calculated for both species of owls. Amphibians, reptiles, and insects constitute some portion of the diet of both species of owls. However, because of the difficulty in determining the number of individuals of amphibians, reptiles, and insects present in pellets, they have not been considered in the following calculations. The relative occurrence of prey in the Great Horned Owl pellets consisted of 90.1 percent mammals and 9.9 percent birds, and in

Table 1. NUMBER OF INDIVIDUAL MAMMALS IDENTIFIED IN THE PELLETS OF GREAT HORNED OWLS. LOCATION GIVEN AS SECTION, TOWNSHIP, RANGE, WEST 4th MERIDIAN.

Species

Masked Shrew

Hayden's Shrew

Vagrant Shrew

Bat

Nuttall's Cottontail

White-tailed Jack Rabbit

Richardson's Ground Squirrel

Northern Pocket Gopher

Olive-backed Pocket Mouse

Deer Mouse

Northern Grasshopper Mouse

Meadow Vole

Long-tailed Vole

Sagebrush Vole

Muskrat

Ermine

Least Weasel

Long-tailed Weasel
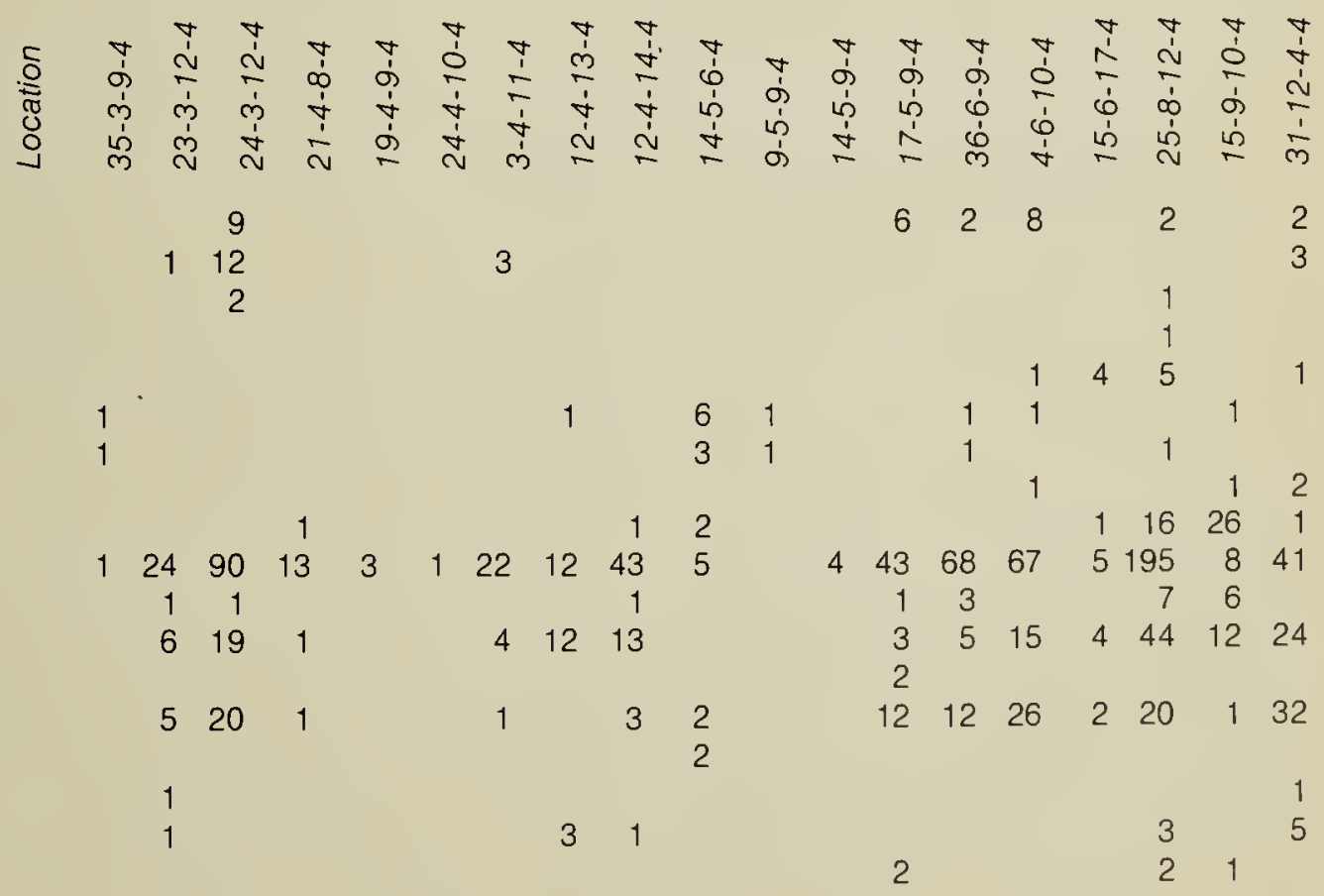
Table 2. NUMBER OF INDIVIDUAL BIRDS FOUND IN THE PELLETS OF GREAT HORNED OWLS. NOTE: $X$ INDICATES PRESENCE OF ANIMAL AT THAT LOCATION AS INDICATED BY REMAINS FOUND IN PELLETS. LOCATION GIVEN AS SECTION, TOWNSHIP, RANGE, WEST 4th MERIDIAN.

Species

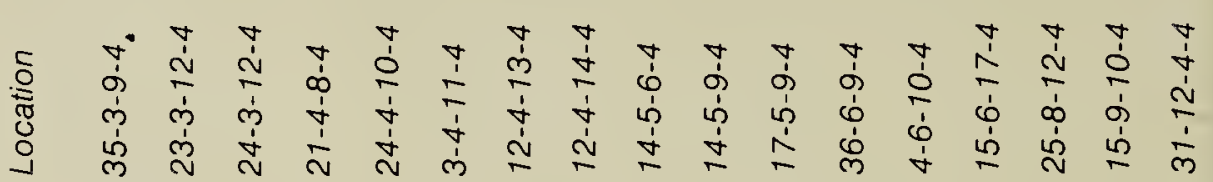

Horned Grebe

Eared Grebe

Mallard

Gadwall

Pintail

Green-winged Teal

Blue-winged Teal

Shoveler

Redhead

Lesser Scaup

Marsh Hawk

Sharp-tailed Grouse

Gray Partridge

American Coot

Killdeer

Willet

Greater Yellowlegs

Lesser Yellowlegs

Rock Dove

Burrowing Owl

Short-eared Owl

Horned Lark

Barn Swallow

Black-billed Magpie

Common Crow

Black-capped Chickadee

Mountain Bluebird

House Sparrow

Red-winged Blackbird

Common Grackle

Savannah Sparrow

Clay-colored Sparrow

Unidentified Bird

Salamander

Insects

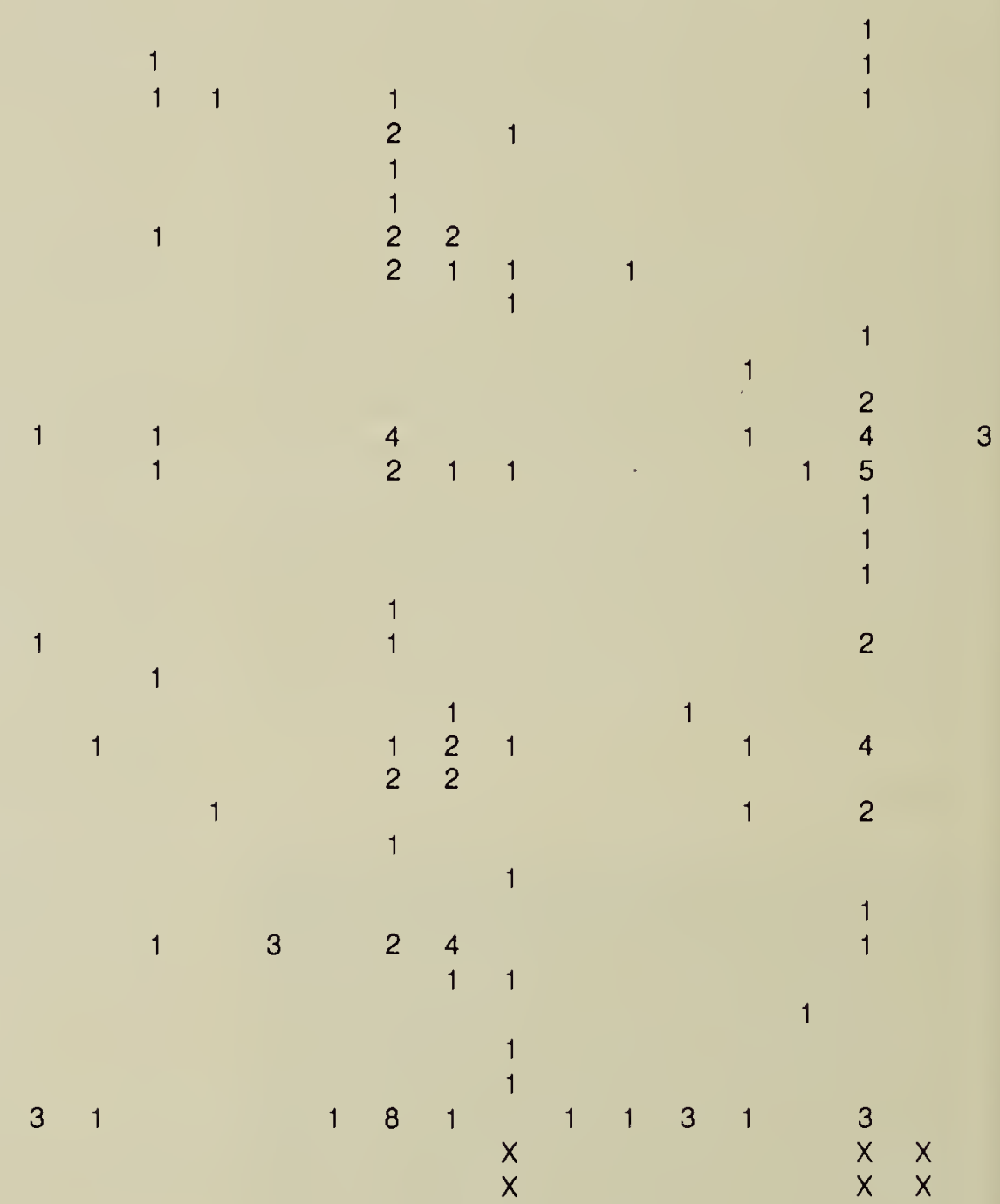

Table 3. NUMBER OF INDIVIDUAL MAMMALS IDENTIFIED IN THE PELLETS OF BURROWING OWLS. LOCATION GIVEN AS SECTION, TOWNSHIP, RANGE, WEST 4th MERIDIAN.

Species

Masked Shrew

Hayden's Shrew

Vagrant Shrew

Richardson's Ground Squirrel

Northern Pocket Gopher

Olive-backed Pocket Mouse

Deer Mouse

Northern Grasshopper Mouse

Meadow Vole

Sagebrush Vole

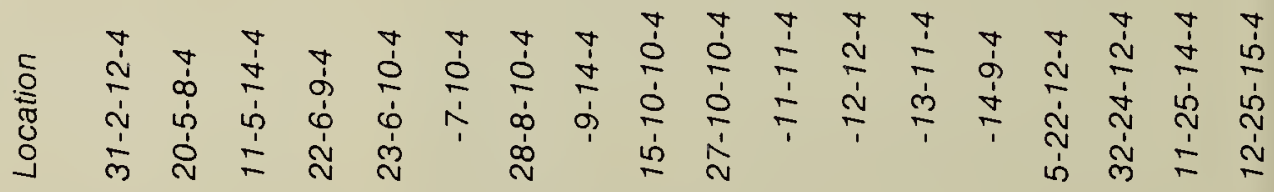

$$
\begin{aligned}
& \begin{array}{l}
8 \\
9
\end{array}
\end{aligned}
$$

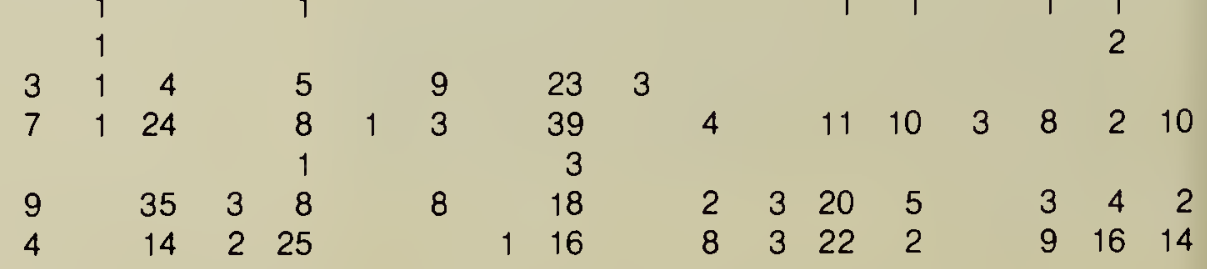


Table 4. NUMBER OF INDIVIDUAL BIRDS FOUND IN THE PELLETS OF BURROWING OWLS. NOTE: $X$ INDICATES PRESENCE OF ANIMAL AT THAT LOCATION AS INDICATED BY REMAINS FOUND IN PELLETS. LOCATION GIVEN AS SECTION, TOWNSHIP, RANGE, WEST 4th MERIDIAN.

Willet

Burrowing Ow!

Horned Lark

Black-capped Chickadee

Rock Wren

Mountain Bluebird

Rufous-sided Towhee

Savannah Sparrow

White-throated Sparrow

Unidentified Bird

Gartersnake

Salamander

Insects

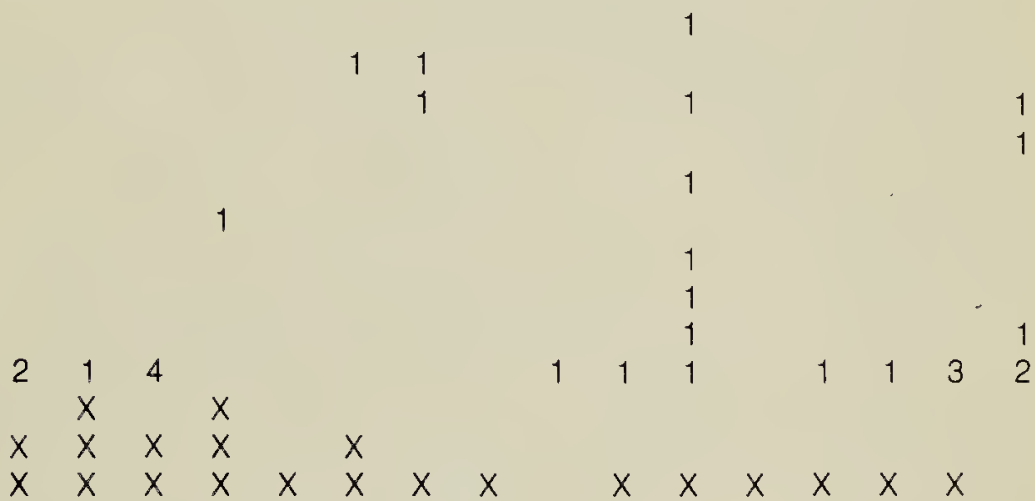

the burrowing owl pellets 94.1 percent mammals and 5.9 percent birds.

\section{Annotated Mammal List}

MASKED SHREW (Sorex clinereus) Both species of owls preyed on this shrew. It is widely distributed throughout the area and is locally abundant.

HAYDEN'S SHREW (Sorex haydeni) Van Zyll de Jong found that two forms of the common shrew occurred in southern Alberta." They are sufficiently different to be classified as separate species. One method of separating them was on the basis of pigmentation on the anterior toothrow of the lower jaw. If Sorex haydeni is a valid species and pigmentation is a reliable method for differentiating it from Sorex cinereus, then the records reported here provide additional distributional information on this shrew.

Both species of owls preyed on this shrew. It is evidently widely distributed and locally common. As Van Zyll de Jong pointed out this species occurs sympatrically with Sorex cinereus. ${ }^{11}$

DUSKY SHREW (Sorex monticolus) This shrew was found in Great Horned Owl pellets from two localities and burrowing owl pellets from one locality. The small number of individuals taken and their wide distribution indicates that this species is not common on the grasslands of Alberta.

BAT (possibly Myotis volans) A proximal end of a humerus and a left upper cheek toothrow were recovered from a Great Horned Owl pellet. This is the first evidence of owl predation on bats in Alberta. On direct comparison with skulls of Little Brown Bat, Myotis lucifugus, and Long-legged Bat, Myotis volans, the teeth appeared to match those of the Long-legged Bat more closely.

NUTTALL'S COTTONTAIL (Sylvilagus nuttallii) This species was found only in Great Horned Owl pellets. Examples were found at four widely scattered sites. At two of these sites remains of four and five individuals were obtained while single individuals were recovered at the other two sites. Collectors have found cottontails to be locally abundant in southern Alberta. ${ }^{10}$ The number of cottontails found in this study may reflect this or it may indicate that the owls at two sites were showing a preference for cottontails, as had been reported in the literature. ${ }^{6}$ 


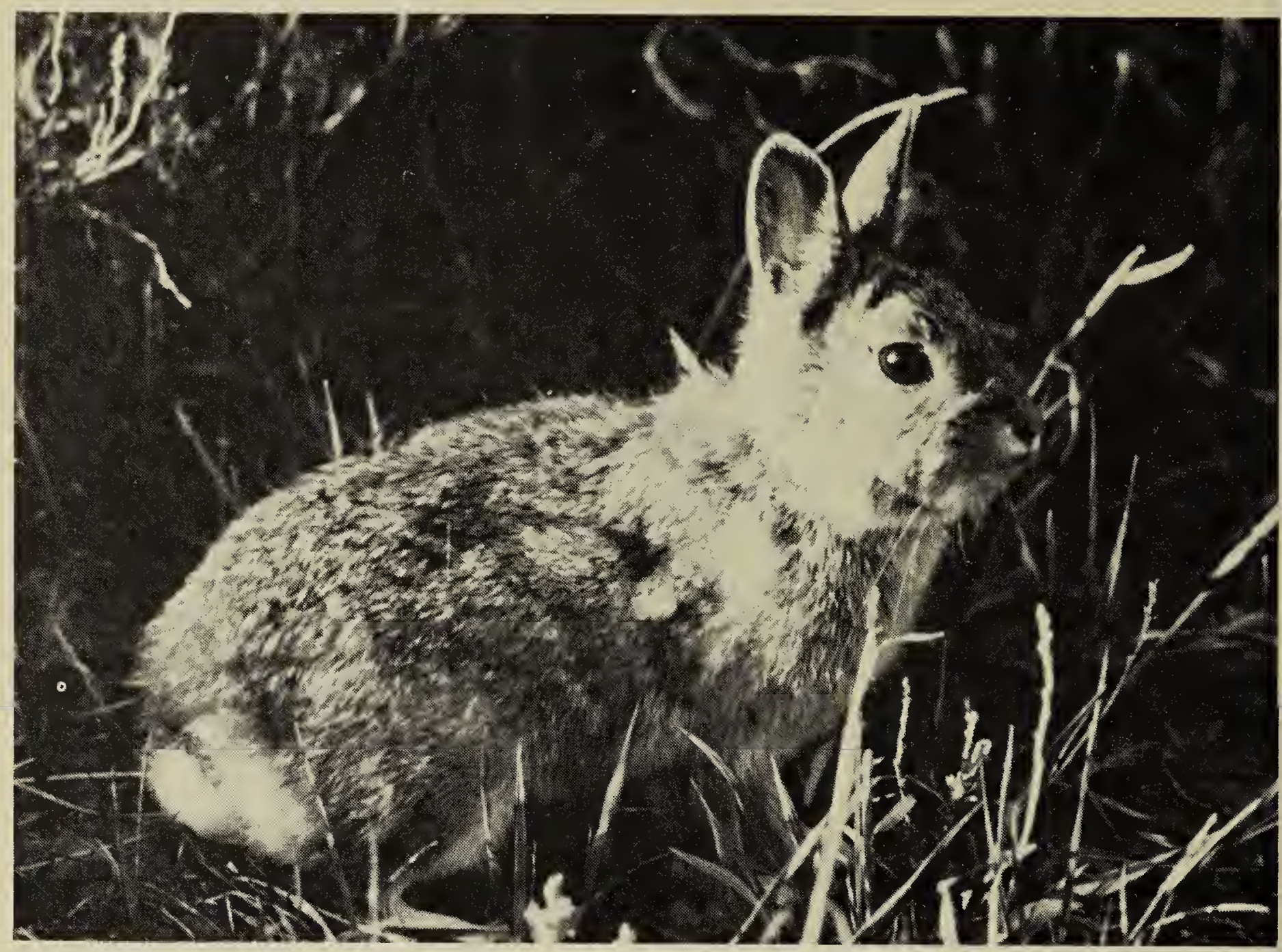

Nuttall's Cottontail.

Gary W. Seib

\section{WHITE-TAILED JACK RABBIT (Lepus} townsendii) Remains of jack rabbits were found in Great Horned Owl pellets from seven widely separated sites. Six individuals, all appearing to be immature, were recovered from one site. In north central Alberta Rusch et al. found that Snowshoe Hares (Lepus americanus) are important food items in the diet of Great Horned Owls. ${ }^{8}$ What role jack rabbits assume in the diet of these birds in southern Alberta remains to be studied. The distribution of pellets in which remains of jack rabbits were found reflects the wide distribution of this hare in southern Alberta.

RICHARDSON'S GROUND SQUIRREL (Spermophilus richardsonii) Remains were found in pellets from five Great Horned OWl and six Burrowing Owl sampling localities. It is not known whether the Burrowing Owls were preying on these ground squirrels or were eating them as carrion. Coulombe suggested that the remains of a ground squirrel found at a Burrowing Owl roost in California represented carrion. ${ }^{2}$ On the other hand, Longhurst included Thirteen-lined Ground Squirrel Spermophilus tridecemlineatus, in the food items of Burrowing Owls in Colorado without comment. ${ }^{5}$ Until further studies are done on the food habits of Burrowing Owls in Alberta it is not possible to make any firm statement on this subject. However, the frequency of ground squirrels in the pellets of Burrowing Owls would seem to indicate predation rather than scavenging.

On the basis of the evidence apparent in this study this ground squirrel is widely distributed throughout the area.

NORTHERN POCKET GOPHER (Thomomys talpoides) Pocket gophers were not important items in the diet of either owl species in southern Alberta. Four individuals from three areas and three individuals from two other areas were found in pellets of Great Horned Owls and Burrowing Owls respectively.

Pocket gophers are not common in southern Alberta but are perhaps widely distributed as this study may indicate. 
LEAST WEASEL (Mustela nivalis) Thirteen individuals were identified in five widely scattered Great Horned Owl samples. On this basis, these weasels are widely distributed and locally common. Hall ${ }^{3}$ lists the Great Horned Owl as an "enemy" of this weasel and cites a study in which remains of a Least Weasel were recovered from a Great Horned Owl pellet. Least Weasels are also preyed upon by Snowy Owls.'

LONG-TAILED WEASEL (Mustela frenata) Five individuals from three samples of Great Horned Owl pellets were identified. Hall does not include owls in his list of predators for this weasel and cites a study done by Pearson and Pearson that states that (weasels) "were never eaten by owls." 37 Boxall and Rusch et al. include this weasel in the diets of Snowy Owls and Great Horned Owls respectively. ${ }^{8}$ The evidence found in this study would indicate that these weasels are not preyed on extensively by owls in southern Alberta.

\section{DISCUSSION}

Great Horned Owls preyed upon insects and amphibians less frequently than did Burrowing Owls. Insect and salamander remains were found in pellets from only three of the 19 Great Horned Owl localities, whereas insects were found in 14 of 18 Burrowing Owl localities and salamanders in six of these 18 sites (Table 5).

The number of species of mammals that are used as food by both species of owls is extensive. The only limiting factor for preying on an animal would seem to be the size of the prey item in relation to the size of the owl. ${ }^{4}$ By using the ranges of mammals as given by Soper ${ }^{10}$ and mammal size, I identified 28 species as potential prey for the Great Horned Owl and 22 species as potential prey for the Burrowing Owl. If bats are eliminated as "normal" prey, the number of species available is 22 and 16 respectively. Using these latter figures, Great Horned Owls use 77 percent of the available mammal species and Burrowing Owls use 62.5 percent. Rodents make up the greatest percentage of mammalian orders used by both owls (Table 6 ). Deer Mice and Grasshopper Mice together are the most important prey species items for Great Horned Owls, while voles are most important for Burrowing Owls (Table 7).

\section{Great Horned Owl}

In other studies conducted on the food habits of Great Horned Owls, leporids (rabbits and hares) are considered to be the principal prey species. ${ }^{6}$ Rusch et al. used biomass of prey to indicate what mammal groups constitute the most important elements in the diet of Great Horned Owls. ${ }^{8}$ They estimated that the daily food requirement for an adult Great Horned Owl was 144 grams but that a daily ration of 310 grams biomass was consumed. Boxall pointed out that when Snowy Owls prey on White-tailed Jack Rabbits they probably ate only one meal from the carcass due to freezing temperatures. ${ }^{1}$ Assuming that this is true for Great Horned Owls as well, and using a daily ration figure of 310 grams as the mass of food consumed from any animal whose weight is greater than 310 grams, a different picture emerges with respect to the various mammalian groups in the diet of this species. Using this method, rodents comprise 77.5 percent of the total biomass of prey and lagomorphs 17.8 percent. These figures may reflect more accurately the importance of these two groups of mammals in the diet of Great Horned Owls in southern Alberta.

\section{Burrowing Owl}

No comparable studies have been made on the daily nutritional requirements for Burrowing Owls. In Colorado Marti found that Burrowing Owls were limited in the size of prey they took but within the limitations of size their diet was variable. ${ }^{6}$ This observation is confirmed in this study as well. It is interesting to note that in Marti's study jack rabbits, a large duck, and a domestic 
cat were consumed by Burrowing Owls. They were, however, considered as carrion rather than prey. Marti suggested that it is more economical for Burrowing Owls to use insects as food because of their abundance and ease of capture. This may be true in Alberta as well, but is not evident by the analysis of pellets. One problem with Burrowing Owl pellets is that if they are composed principally of insect parts they disintegrate faster than pellets comprised principally of vertebrate matter. ${ }^{6}$ This could easily bias the results of pellet analysis more strongly in favor of vertebrates. I made no attempt to quantify the insect prey used by these owls, but under any circumstances, the biomass of vertebrates consumed would be much greater than the invertebrates.

The mammalian component in the diet of Burrowing Owls was larger both in numbers and diversity of species in comparison to other vertebrate prey items (Tables 3 and 4). Rodents were by far the most important mammal order utilized as prey (Table 6). Voles form the largest component of this group (Table 7).

Table 5. NUMBER OF SAMPLE SITES FROM WHICH PREY ITEMS WERE IDENTIFIED

Great Horned Owl

19

17

0

3

3
Burrowing OWI

18
13
2
6
14

Table 6. PERCENT OF MAMMAL ORDERS IN DIET

Great Horned Owl

Insectivora

Chiroptera

Lagomorpha

Rodentia

Carniviora

\section{5}

$\mathrm{Tr}$.

2.0

91.7

1.8
Burrowing OwI

6.9

-

Table 7. PERCENT OF RODENTS IN DIET

Large Rodents

(ground squirrels, pocket gophers, muskrats) 


\section{Conclusions}

The analysis of pellets from Great Horned Owls and Burrowing Owls is useful in obtaining an understanding of the distribution of small mammals in an area. In this study it was possible to "fill in gaps" in the knowledge of the distribution of many of the small mammals of southeastern Alberta. This study also showed that rodents are the principal mammal group preyed on by these owls.

I wish to thank D. Schowalter, formerly of Alberta Fish and Wildlife Division, for collecting these owl pellets and for making them available to me.

'BOXALL, P.C. 1980. Aspects of the behavioural ecology of wintering snowy owls (Nyctea scandia). Unpublished MSc. Thesis, University of Calgary. 213 pp.

${ }^{2}$ COULOMBE, H.N. 1971. Behavior and population ecology of the Burrowing Owl, Speotyto cunicularia, in the Imperial Valley of California. Condor 73:162-176.

${ }^{3} \mathrm{HALL}$, E. R. 1951. American weasels. University of Kansas, Publ. Volume 4:1-466.
${ }^{4} \mathrm{KORSCHGEN,} \mathrm{L.} \mathrm{J.} \mathrm{and} \mathrm{H.} \mathrm{B.} \mathrm{STUART.}$ 1972. Twenty years of avian predator small mammal relationships in Missouri. Jour. Wildl. Mgmt. 36:269-282.

${ }^{5}$ LONGHURST, W. M. 1942. The summer food of Burrowing Owls in Costilla County, Colorado. Condor 44:281-282.

${ }^{6} \mathrm{MARTI}, \mathrm{C} . \mathrm{D} .1974$. Feeding ecology of four sympatric owls. Condor 76:45-61.

'PEARSON, O.P. and A. K. Pearson. 1947. Owl predation in Pennsylvania, with notes on the small mammals of Delaware County. Jour. Mammal. 28:137-147.

${ }^{8}$ RUSCH, D. H., E. C. MESLOW, P. D. Doerr and L. B. KEITH. 1972. Response of Great Horned Owl populations to changing prey densities. Jour. Wildl. Mgmt. 36:282-296.

${ }^{9}$ SMITH, H. C. 1976. Comparison of food items found in pellets of seven species of owls. Edmonton Naturalist 4:36-38.

${ }^{10}$ SOPER, J. D. 1964. Mammals of Alberta. Queens Printer, Edmonton. 402 pp.

"VAN ZYLL de JONG, C. G. 1980. Systematic relationships of woodland and prairie forms of the Common Shrew, Sorex cinereus cinereus and $S$. $c$. haydeni Baird, in the Canadian prairie provinces. Jour. Mammal. 61:66-75.

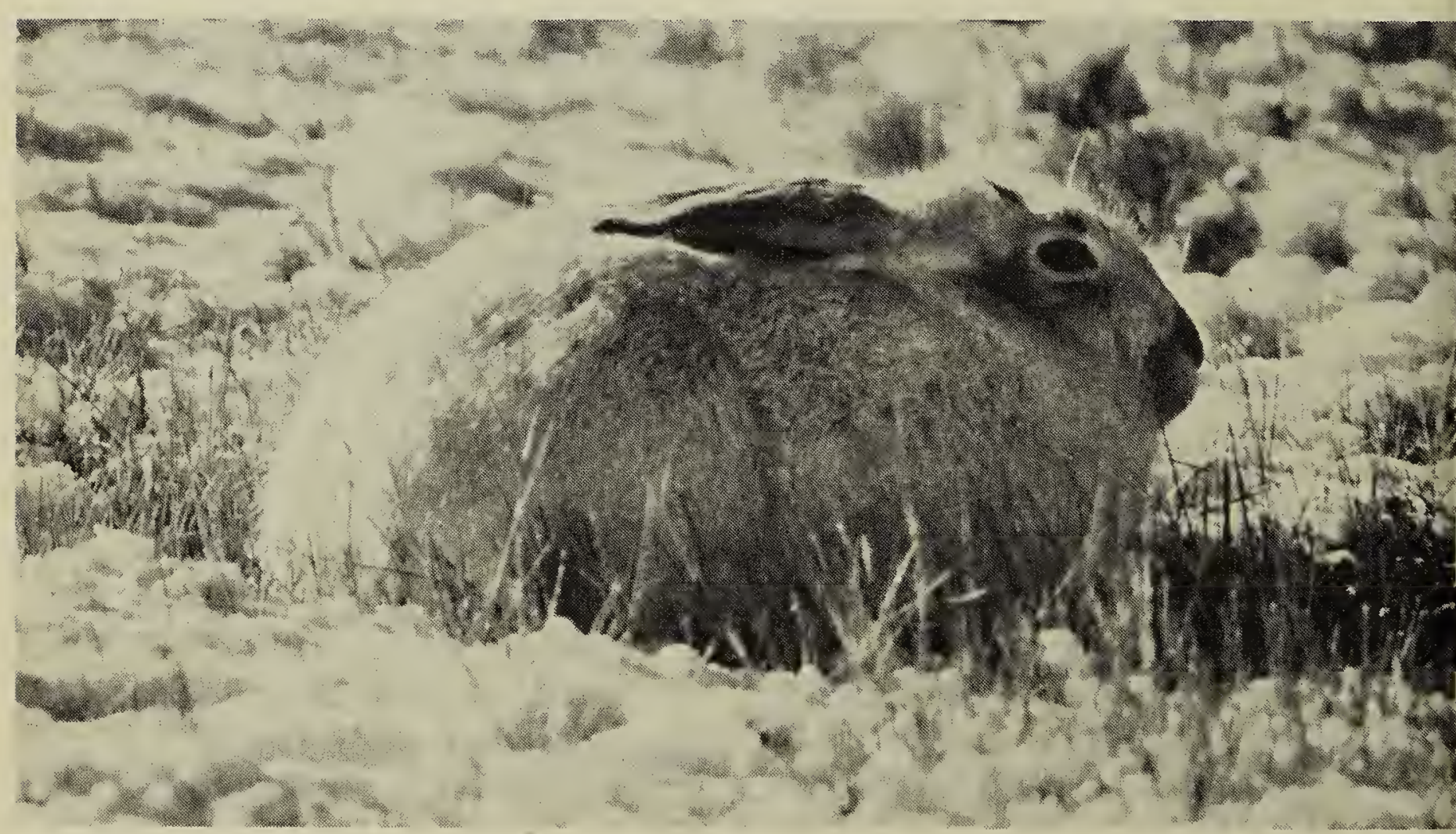

White-tailed Jack Rabbit.

Lorne Scott 